\title{
E. Skakalina
}

National University "Yuri Kondratyuk Poltava Polytechnic", Poltava, Ukraine

\section{APPLICATION OF ANT OPTIMIZATION ALGORITHMS IN THE SOLUTION OF THE ROUTING PROBLEM}

\begin{abstract}
The article discusses current issues of using evolutionary algorithms to solve the routing problem. Ant algorithms (MA), like most types of evolutionary algorithms, are based on the use of a population of potential solutions and are designed to solve combinatorial optimization problems, first of all, search for various paths on graphs. The cooperation between individuals (artificial ants) is implemented on the basis of stigmetry modeling. In addition, each agent, called artificial ant, is looking for a solution to the problem. Artificial ants consistently build a solution to the problem, moving around the graph, lay the pheromone and, when choosing a further section of the path, take into account the concentration of this enzyme. The higher the concentration of pheromone in the subsequent section, the greater the likelihood of its choice. Since MA is based on the movement of ants along some paths, MAs are effective, first of all, in solving problems that can be interpreted in the form of a graph. Computer experiments showed that the efficiency of MA increases with increasing dimension of the problem and for tasks on high-dimensional graphs they work faster than other evolutionary algorithms. Good results were also noted in solving non-stationary problems on graphs with a changing environment. In connection with this, the implementation of the meta - heuristic method is proposed as a modification of ant optimization algorithms. The scheme of the system is presented. A software product specification is also provided.
\end{abstract}

Keywords: evolutionary algorithms, routing problem, ant optimization algorithms.

\section{Introduction}

In the process of managing complex technical and organizational-technical systems it is necessary to constantly make difficult decisions related to the consideration of many quality criteria and restrictions on resources. If you make such decisions using only the intuition and experience of the manager, it will be difficult to make the best choice. In this regard, it is necessary to develop and implement formalized methods of decision support. Formal mathematical decision-making models nowadays increasingly reflect the complexity of real-world practical problems, which, on the one hand, make them more relevant to real systems, and, on the other, lead to the need to solve increasingly complex optimization problems.

The basic properties of real-world practical optimization problems - the presence of many criteria, significant constraints, multidimensional variables, and algorithmic task functions - make it impossible to apply traditional methods. The way out of this situation is to use adaptive stochastic algorithms, successfully overcome these difficulties. One of the most commonly used approaches in this setting is evolutionary algorithms, which are stochastic optimization procedures that mimic natural evolution processes, in particular, genetic algorithms (GA). The algorithmic function assignment and the multidimensionality of the variables do not present additional difficulties for GAs who work with binarized representations of solutions and do not require information about the properties of the target functions. However, the presence of many criteria and limitations complicate the use of GA in practical tasks, ie. most approaches proposed in the field of evolutionary optimization are focused on only one problem, that is, either multicriteria, or constraints.

Approaches combining both areas are rare and their effectiveness is not always satisfactory. Optimization and planning of cargo flows, finding rational routes result in significant savings of enterprise resources. With the correct implementation of the task, you can minimize production costs by $5-8 \%$ and significantly improve the quality of service recipients, improve the efficiency of production processes of the enterprise. One way to save resources when transporting goods is to use decision support systems (DSS) in the field of transport logistics. Development of software packages that solve basic ones the task of this field requires serious scientific research in order to obtain efficient algorithms suitable for for everyday use. One of the key features of the DSS is the in the field of transport logistics there is an opportunity of calculation and construction effective in terms of detours for various routes on the transport network. This problem is most common among companies that carry goods from some warehouse to points of consumption or retail.

The mathematical formulation of this problem is commonly known as the Transport Routing Problem. There are a number of types of TRP with different additional conditions that allow to take into account the load capacity of vehicles and other restrictions for a more complete presentation of the details of real reality. TRP is a generalization of the known task challenge of the traveler (CT) in case of construction right away several closed routes passing through some common summit - the so-called "depot". TRP and CT belong to the class of discrete problems optimization and are NPheavy. There are no methods of finding their exact solutions and optimality testing for approximations of polynomial time. There is a known exact algorithm for the solution of TRP based on the method branches and boundaries, but due to the extremely fast computation time it cannot be used for tasks with more than 25-30 vertices.

An overview of the latest sources of research and publications

The development of methods and means of artificial intelligence allows to apply them to an 
increasingly wide range of problems and problems of optimal control theory in particular. First and foremost, this applies to tasks that are obtained only approximate solution methods or the solution of exact methods is quite large. To the class of such problems is undoubtedly one of parametric optimization of various kinds of automatic systems according to the criteria of different species. A modern trend in the design and development of automatic control systems (ACS), and the DSS is used not only integral, but also other, nonstandard criteria [1], as well as an increase in the number of adjustable parameters. All this makes researchers when solving problems of parametric optimization to turn to new methods and tools, including to such relatively new artificial intelligence technique like genetic algorithm. The increase in foreign $[2,3,4,5,6,7,8]$ and domestic $[9,10,11,12,13]$ publications on the subject testifies to the considerable interest of researchers to this kind of problem. A great contribution to the application of genetic algorithm for solving various optimization problems introduced John Holland [14], K. A. De Jong [15] etc.

However, with all the diversity of publications, a number of questions remain unresolved regarding the application of the genetic algorithm to solve the problem of parametric optimization for automated systems, which makes such studies relevant

\section{Basic material and results}

2.1. Optimization tasks and their place in road transportation planning

Currently, one of the main ways to improve the quality and efficiency of freight traffic is to choose the options for the use of vehicles, which include a number of tasks, in solving each of which, from obtaining an order for transportation, from the many options should be selected optimal, that is, the best.

Depending on the type of problem being solved, a specific metric is selected for which it seeks to find the best value (for example, the minimum ATS run, the maximum profit, etc.). This indicator is called the optimality criterion and is a function of the independent parameters (output) of the problem:

$$
F=F\left(x_{1}, x_{2}, \cdots, x_{n}\right)
$$

The decrease or increase in the value of the criterion of optimality is determined by the need to fulfill different customer requirements, road conditions, vehicle technical parameters, etc. Indicators and characteristics to which constraints are imposed are also functions of independent parameters and are called constraint functions that can be given in the form of equalities and inequalities

$$
\begin{gathered}
R_{i}=R_{i}\left(x_{1}, x_{2}, \cdots x_{n}\right)=0 \\
R_{j}=R_{j}\left(x_{1}, x_{2}, \cdots, x_{n}\right) \leq 0 ; \quad x_{k} \leq 0
\end{gathered}
$$

When solving optimization problems, it is necessary to define and substantiate the optimality criterion and to clearly identify the indicators and characteristics that are accepted as constraints. The set of formulas that allow for a given set of parameter values to calculate the values of the constraint functions and the optimality criterion are called a mathematical model.

\subsection{Features of transport optimization problems.}

The widespread use of optimization methods in road transport is inextricably linked with the development of computer facilities, which allows to find the optimal solution in the online mode, taking into account the changing environment. Thus, the choice of the best option is the next, natural step in the higher organization of planning and management of road transport.

The specific properties of the tasks of planning the transport process, especially the tasks of operational planning, which caused the need to involve a mathematical apparatus of modern computer facilities, the following:

- The overwhelming number of such tasks are multivariate. The variety of types of vehicles (TRPs), the large number of their locations, loading and unloading points leads to a huge number of possible delivery options (for example, when solving the problem of fixing eight consumers for five suppliers, hundreds of millions of options are possible). Typically, dozens of trucking organizations, hundreds of suppliers and thousands of consumers are involved in solving practical problems.

- Tasks are characterized by a limited time to process the source information, since although there is a premature receipt of primary information (ten days, five days, months), daily and even hourly corrected information arrives, which can not lead to distortion of the real situation, receiving unnecessary to practice the results.

- Significant initial task sizes. This property is especially characteristic of large industrial centers, where there are a large number of motor transport organizations (MTO), shipment and shipment points (GDP, WFP).

- The presence of a large number of significant restrictions, which may not lead to unacceptable transportation options. This is first of all a limitation: on the time of operation of the TRP on the line; downtime under loading and unloading; GDP and WFP throughput; time of export and delivery of

- cargo; dependence between TRP type and type of cargo, etc.

- Different periodicity of the decision. The period of solving the problems of optimization of cargo flows depends largely on the level of organization, on the technological properties of the goods being delivered, etc.

- When planning the transport process, the number of unloading points far exceeds the number of loading points. This requires special studies and measures related to the aggregation (consolidation) of Consumption Points (WFP), which, on the one hand, reduces the complexity of calculations for computers, and on the other hand increases the cost of processing information and leads to some deviations from the best results.

\subsection{Basic methods of optimal planning of cargo} transportation

Depending on the tasks to be solved in the practice of transportation planning, various mathematical methods are used to obtain optimal solutions. Due to the 
fact that as a criterion of optimality, as a rule, use economic indicators, often such methods are called economic and mathematical methods.

2.4. Modeling of transport networks and calculation of the shortest distances.

When planning the transport the need arises in the definition of the shortest distances between the transportation company (MTC), points of consumption and points of departure of the goods. The shortest distance between points are the basis for the payment by the customer of transport services, for metering of fuel, determination of turnover, payroll drivers, etc.

Determination of the distance of transportation. Determination of the distance of transportation is carried out in several practical ways.

Direct measurement of the distance on the ground. This method is not useful through long distances that cargoes are transported.

Running routes in the vehicle can be carried out on the basis of the testimony of the regular speedometer or special meter distances, which is an optional wheel with the device for fixing the speed. The distance traveled is determined by the formula

$$
L_{M}=2 \pi R_{K} n_{K},
$$

where the radius of the wheel; the number of revolutions.

Measurement on the map (plan) of the city or district for help curvimeter.

All these methods have one serious drawback: there is no guarantee that the selected path is the shortest. This disadvantage is especially true with a densely branched road networks in modern cities, when between distant points in many different ways. To find the optimal solutions using mathematical techniques, the application of which requires as input the transport network, reflecting the transport connections between different points.

Build a model of the transport network. The set of all roads of a city or region is the road network. The transport network is a set of roads in the region, suitable for the movement of specified vehicles. The transport network is always a particular case of the road network, usually built for different types of vehicles: cars, trucks with full weight up to 3.5 tons, etc.

The model network can be represented as a graph. A graph is a figure consisting of points (vertices) and segments connecting them (links). The vertices of the graph are points on the network, most important to determine distances or routes.

The links in the graph are segments of the transport network that characterize the presence of a road connection between adjacent vertices. The links in the graph are characterized by numbers that may have different physical meanings. Most often this is the distance, but can also be used, for example, travel time. The direction-oriented links in the graph are called arcs. Virtually every undirected link in a graph includes two equal but opposite arcs. Depending on whether all or part of the links are directed, the graph is oriented or mixed. A graph, each vertex of which can be connected by some sequence of links to any other vertex, is called a bound graph. In other words, each vertex of a connected graph must have at least one input and one output arc. The graph modeling the transport network must be connected so that from any vertex there is always a path to any other vertex. Characteristic numbers the links of such a graph, usually expressing the length of the path, time or cost of travel. For modeling of the transport network must have: maps, usually maps on a large scale, as they allow with high accuracy to measure distances between points; data on the location of the main OSF and off; additional information from the municipal and road organizations in the form of a list of streets with the characteristic of the roadway; information on the organization of traffic, i.e., schemes of organization of traffic at intersections, squares and transport interchanges, as well as information about the different limitations of movement associated with the established traffic signs.

With this information, the modeling of transport network starts with the placement of graph vertices. For the vertices of the graph take GDP, WFP and so on. Each vertex is assigned a sequence number or other symbol. After placing the vertices they are connected by arcs or links.

2.5. Algorithms for determining the shortest distances on the graph. The interest in the task of finding the shortest distances is explained by the fact that this task is one of the stages in solving most of the problems related to freight. In the process of solving the problems associated with the optimization of freight traffic, many times determine the shortest distances between the vertices of the graph. Therefore, the speed of the algorithms for determining the shortest distances largely depends on the time of solving the whole problem as a whole.

We formulate the problem of the shortest path. Let be a connected graph having $\mathrm{R}$ vertices and $\mathrm{N}$ oriented arcs, with each arc being assigned a nonnegative number called its length. You need to find the shortest paths and their lengths from the given vertex to all other vertices of this graph.

The length of the shortest path means the sum of the lengths of the arcs that make up this path. Each vertex of a graph can have only one arc, which belongs to any shortest path.

- Dijkstra algorithm - finds the shortest path from one of several vertices of the graph to all others. The algorithm works only for graphs without negative edges;

- Bellman-Ford algorithm - finds the shortest paths from one vertex to all others in a weighted graph. The weight of the ribs can be negative;

- A* search algorithm - finds the route with the least value from one vertex (initial) to the other (destination, final), using the first best matching graph search algorithm;

- Floyd-Worschell algorithm - finds the shortest paths between all vertices of a weighted oriented graph;

- Johnson algorithm - finds the shortest paths between all pairs of vertices of a weighted oriented graph;

- Nearest neighbor algorithm is one of the simplest heuristic methods of solving a traveling salesman problem 
- Nearest insertion algorithm

- Ant algorithm - one of the artificial intelligence methods proposed by M. Dorigo

Among the so-called "Soft computing techniques" developed over the past ten years for hard-to-solve discrete optimization problems are

- Genetic algorithms - based on natural selection and genetics

- Ant algorithms (Ant Colony Optimization $A C O$, Ant Systems - AS) • Model anthill behavior

The imitation of the ant colony self-organization forms the basis of the ant optimization algorithms. An ant colony can be regarded as a multi-agent system in which each agent (ant) functions autonomously by a very simple rule. In contrast to the almost primitive behavior of the agents, the behavior of the whole system turns out to be reasonably reasonable.

Ant algorithms have been seriously studied by European scientists since the mid-1990s. To date, good results have already been obtained to optimize such complex combinatorial tasks as the task of a salesman, the task of optimizing truck routes, the task of coloring a graph, the quadratic task of destination, the task of optimizing network schedules, the task of scheduling, and many others. Particularly effective ant algorithms for dynamic optimization of processes in distributed non-stationary systems, for example, traffic in telecommunication networks.

2.6. Generalized algorithm.

Any ant algorithm, regardless of modifications, will be presented in the following form

- While (exit conditions are not met)

- Creating ants

- Finding a solution

- Pheromone update

- Extra \{optional\}

Now consider each step in the cycle in more detail

- Create ants

- The starting point where the ant is placed, depends on the restrictions imposed by the conditions of the problem. Because for each task the way the placement of the ants is crucial. Or they all fit in one spot, or to either with repetitions or without repetitions.

- At this stage, you specify the initial level of pheromone. It is initialized to a small positive number to the initial step transition probabilities to the next vertex was zero.

- Search solutions

- The probability of transition from vertex $\mathrm{i}$ to vertex $\mathrm{j}$ is determined according to the following formula

$$
P_{i j}=\frac{\tau_{i j}(t)^{a}\left(d_{i j}\right)^{-\beta}}{\sum_{j \in \text { allowed nodes }} \tau_{i j}(t)^{a}\left(d_{i j}\right)^{-\beta}},
$$

where the level of pheromone, $d_{i j}$-distance heuristic, and constant settings.

When $\alpha=0$ the choice of the nearest city, most likely meaning that the algorithm becomes greedy.

When $\beta=0$ the selection is made only on the basis of pheromone, leading to suboptimal solutions.

Therefore, a compromise between these values, which is experimentally.

- Update of pheromone

- The level of pheromone is updated in accordance with the formula

$$
\tau_{i j}(t+1)=(1-p) \tau_{i j}(t)+\sum_{\substack{k \in \text { Colony that } \\ \text { used edqe }(i, j)}} Q / L_{k},
$$

where $\rho$ is the intensity of evaporation of the pheromone, the price of the current solution for the $k$-th anth and $Q$ is the parameter having the value of the order of the optimal solution, that is, the pheromone deposited by the kth anth using the edge $(i, j)$.

- Additional actions

- The local search algorithm is usually used here, but it may also appear after searching for all the solutions.

The scheme of work of system of construction of a route and the schedule of process of gathering of raw materials on the example of Okhtyrsky combine (geographical restriction of the project - Shishatsky area, Poltava region)

Incoming data. The number of vehicles involved in the implementation of raw material collection, the characteristics of vehicles (load capacity), the number of points with raw materials, the distance between fleets and points (in kilometers), geographical coordinates of points (longitude and latitude).

Output data. Optimal transport schedule table, road map with points, list of distances and times between points $\mathrm{AI}$ and $\mathrm{Vj}$, shortest route of all the points mentioned in the transport plan table.

Description of the program. Let the company have 3 vehicles allocated for the collection of raw materials and given a certain territory, including, for example, 10 settlements.

All vehicles have the same characteristics, in our case - the load capacity.

Therefore, to get started with the program, you need to initialize the transport table (Fig. 1)

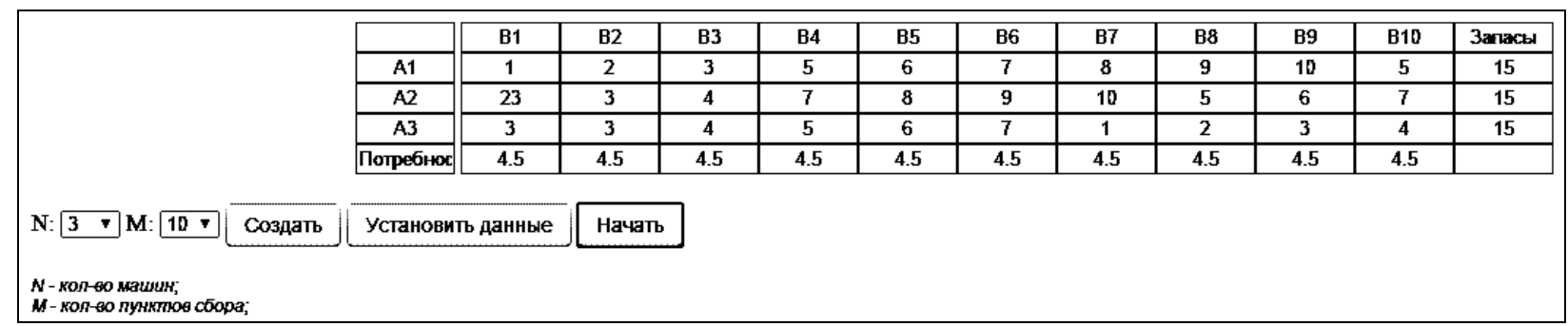

Fig. 1. Transport table initialized 
To do this, select the number of vehicles and the number of items with raw materials from the drop-down lists, and then click on the Create button (Fig. 2). We get an empty transport table (Fig. 3). To fill it with data, first click on the cell marked B1..10 or A1..10 (Fig. 4).

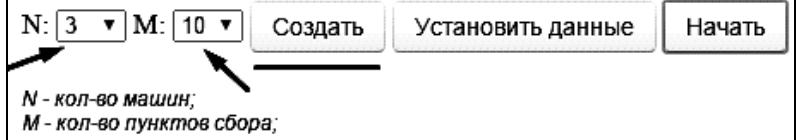

Fig. 2. Creating an input template

\begin{tabular}{|c|c|c|c|c|c|c|c|c|c|c|c|c|c|}
\hline & & & B1 & $\mathrm{B} 2$ & B3 & B4 & B5 & $\mathrm{B} 6$ & $B 7$ & $\mathrm{~B} 8$ & B9 & B10 & Запасы \\
\hline & & $\mathrm{A} 1$ & - & - & - & - & - & - & - & - & - & - & 0 \\
\hline & & $\mathrm{A} 2$ & - & - & - & - & - & - & - & - & - & - & 0 \\
\hline & & $\mathrm{A3}$ & - & - & - & - & - & - & - & - & - & - & 0 \\
\hline & & Потребнос & 0 & 0 & 0 & 0 & 0 & 0 & 0 & 0 & 0 & 0 & \\
\hline $\mathrm{N}: 3 \quad \mathrm{M}: 10 \mathrm{~V}$ & Создать & Установи & анные & Hay & & & & & & & & & \\
\hline
\end{tabular}

Fig. 3. Input transport table

\begin{tabular}{|c|c|c|c|c|c|}
\hline & B1 & B2 & B3 & B4 & B5 \\
\hline $\mathrm{A} 1$ & - & - & - & - & - \\
\hline$\overline{A 2}$ & - & - & - & - & - \\
\hline A3 & - & - & - & - & - \\
\hline Потребнос & 0 & 0 & 0 & 0 & 0 \\
\hline \multicolumn{2}{|c|}{ Установить данные } & Нач & & & \\
\hline
\end{tabular}

Fig. 4. Filling the transport table with input data
Clicking on the selected cell will bring up a dialog where you want to select a settlement from the list and then click on the Confirm button (Fig. 5). After these manipulations, cell B1 will be assigned to Yaresky settlement. When the cells are assigned parameters, you need to click on the "Set Data" button. The program keeps track of the distance between $\mathrm{AI}$ and $\mathrm{Bj}$ in the database and automatically inserts them into the corresponding cell $\mathrm{Cij}$ (Fig. 6). Manual editing is also supported.

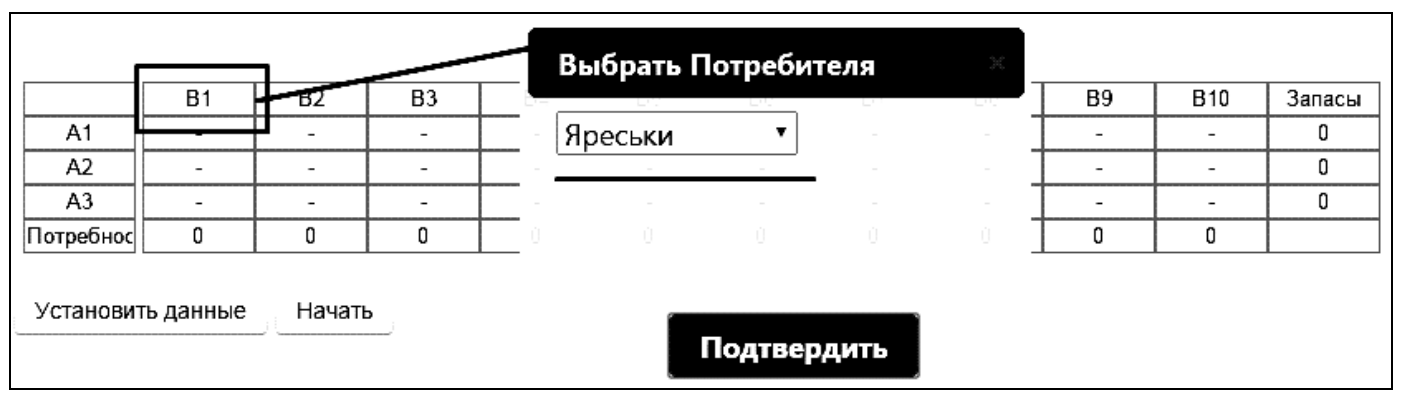

Fig. 5. Consumer choice

\begin{tabular}{|c|c|c|c|c|c|c|c|}
\hline & & B1 & B2 & B3 & B4 & B5 \\
\hline & & A1 & 1 & 2 & 3 & 5 & 6 \\
\hline & & $\overline{\mathrm{A} 2}$ & 23 & 3 & 4 & 7 & 8 \\
\hline & & $\mathrm{A} 3$ & 3 & 3 & 4 & 5 & 6 \\
\hline & & Пөтребню & 4.5 & 4.5 & 4.5 & 4.5 & 4.5 \\
\hline $\mathrm{N}: \begin{array}{llll}3 & \mathbf{M} & \mathrm{M}: 10 & \mathbf{1 0}\end{array}$ & создать & \multicolumn{2}{|c|}{ Установить данные } & $\mathrm{Ha4}$ & & & \\
\hline
\end{tabular}

Fig. 6. Installation of data

As a result, we receive a filled transport table (Fig. 7). It is necessary to click on the "Start" button to start the calculation. After calculations, the program will issue a table of the optimal transportation plan (Fig. 8).

Therefore, raw materials were assigned to all vehicles. Let's choose the first of them (Fig. 9).

Routing. The planning results provided optimal freight, one of which will be considered. Transportation with code A1 must visit points B1, B4, B5, B6. For him, we will initialize the transport table again (Fig. 10), and then click on the button "Build graph".

After that, you will be taken to the page of route construction (Fig. 11).

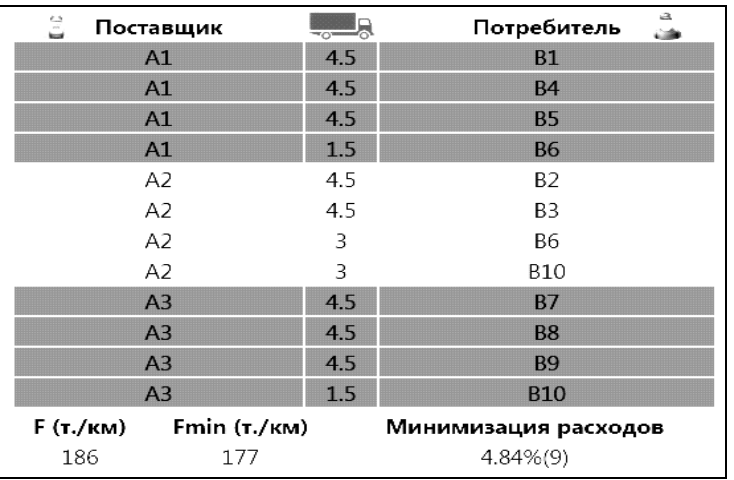

Fig. 7. Table of optimal transportation plan 


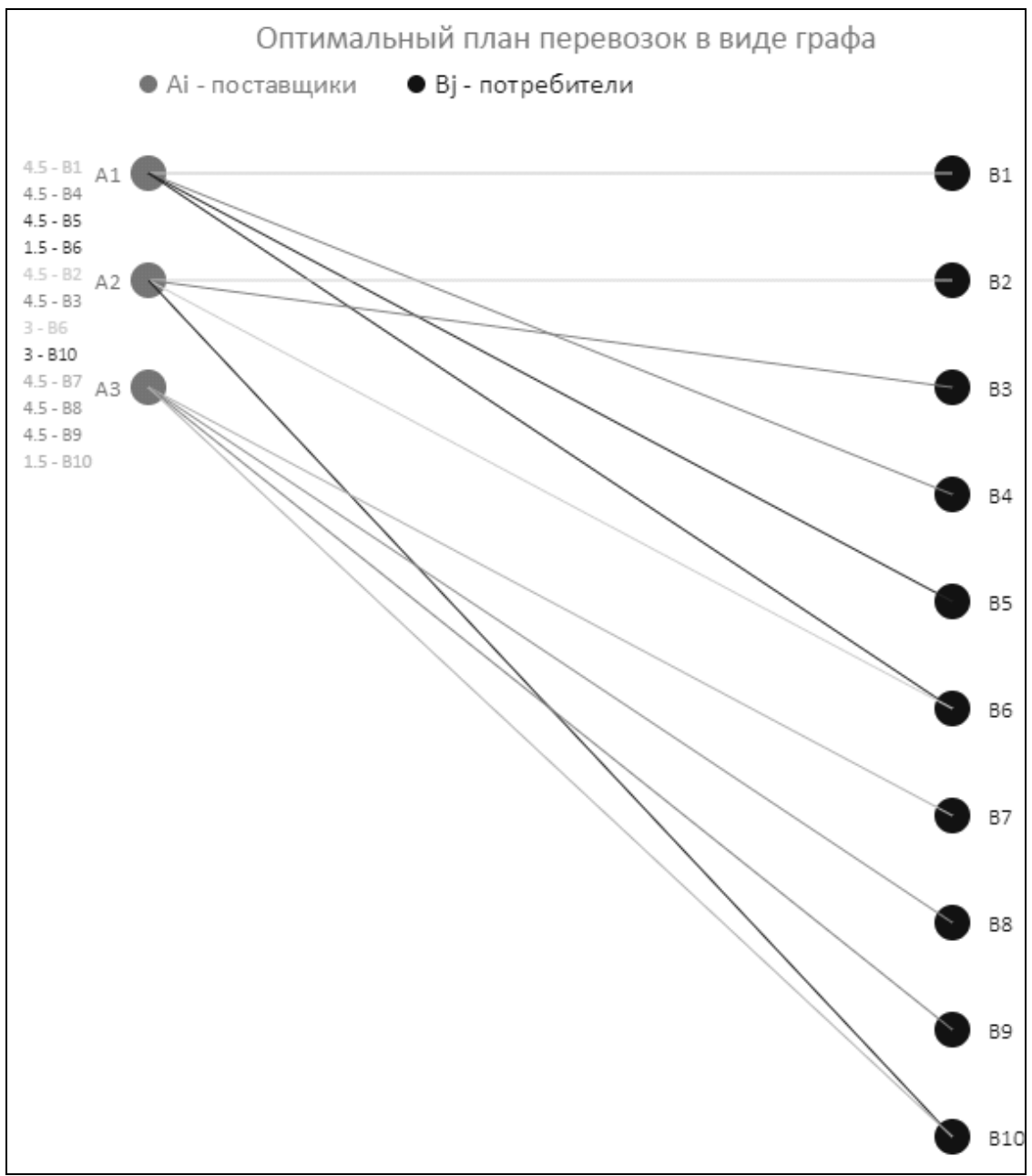

Fig. 8. Optimal plan of transportation in the form of a graph

\begin{tabular}{|l|l|l|}
\hline A1 & 4.5 & B1 \\
\hline A1 & 4.5 & B4 \\
\hline A1 & 4.5 & B5 \\
A1 & 1.5 & B6 \\
\hline
\end{tabular}

Fig. 9. Compliance of vehicles and points with raw materials

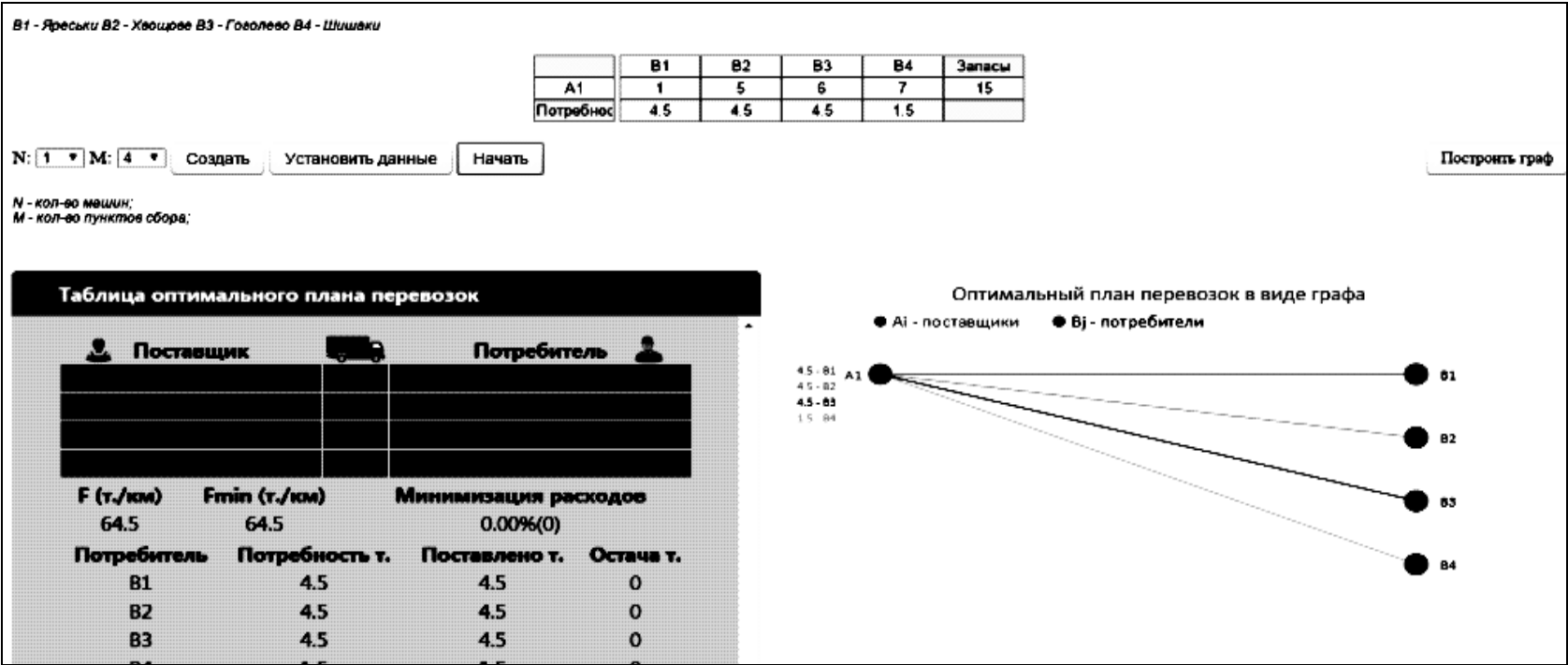

Fig. 10. Transport table 


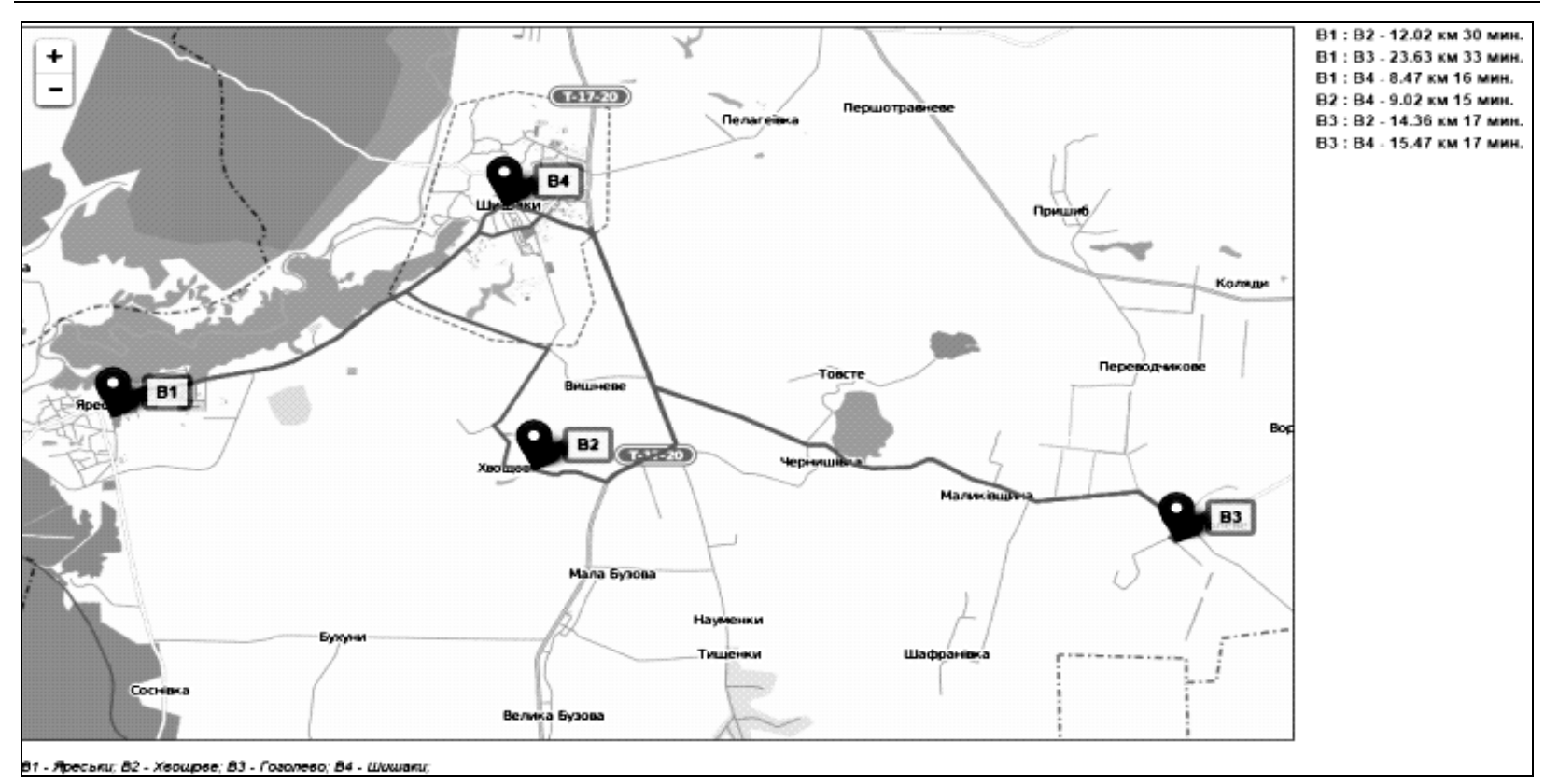

Fig. 11. Construction of the route

The resulting map shows the road network between the points with raw materials. This information shows which roads you should use, their length and time. It is on this grid that a distance matrix search algorithm will look for the shortest route to traverse all points.

2.7. Description of the designed database.

MySQL DBMS was selected for database development (Fig. 12).
The Consumers table is responsible for the information on raw material items and contains the following information: item name, latitude and longitude for determining the location on the map, the amount of raw material that can be offered (Fig. 13, 14).

The "suppliers" table is responsible for the information on the vehicles for raw material collection and contains the following information: name, capacity (Fig. 15).

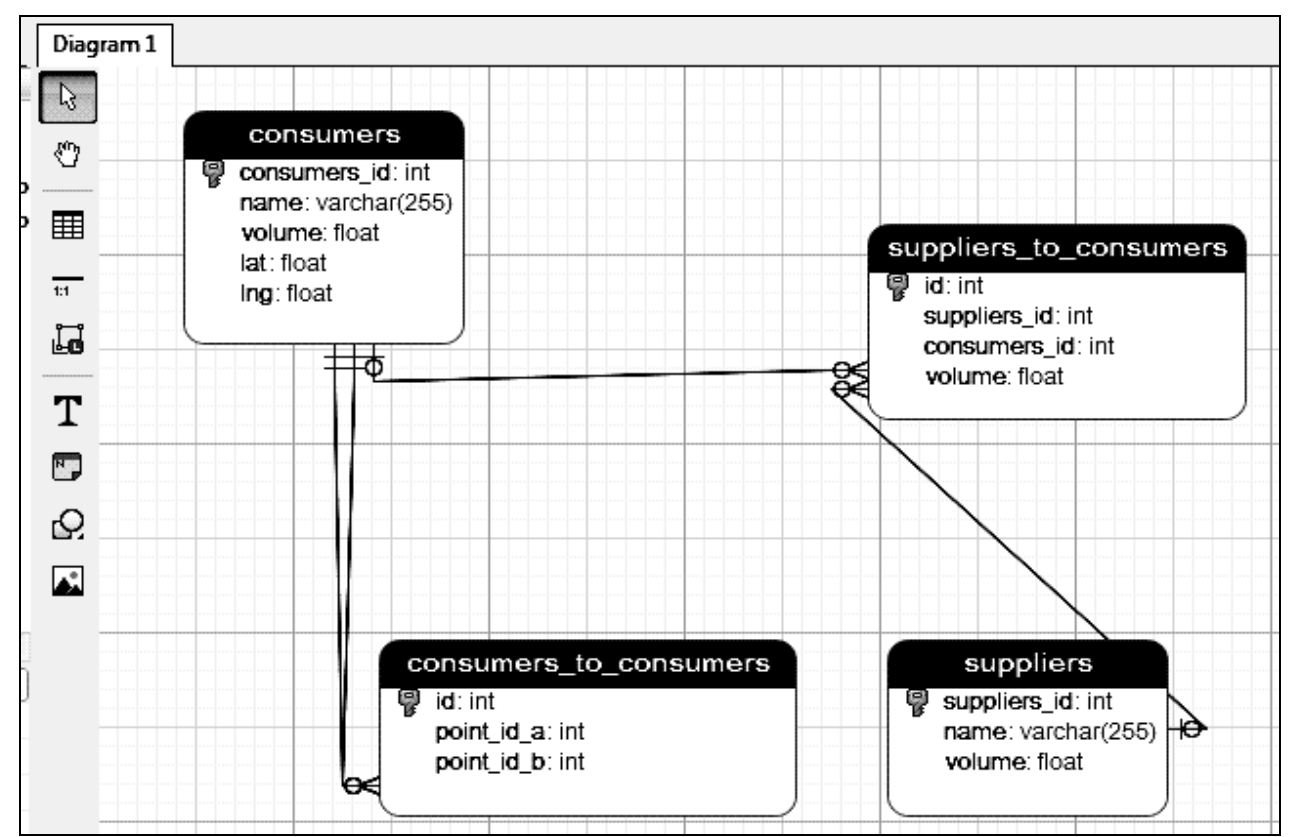

Fig. 12. Database diagram in Navicat

\begin{tabular}{|c|c|c|c|c|c|c|c|}
\hline Столбцы: & \multirow{2}{*}{ (4) Добавить $\Theta$ Удалить } & \multirow{2}{*}{ 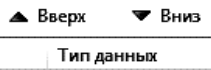 } & \multirow[b]{2}{*}{ Алина/Знач... } & \multirow[b]{2}{*}{ Беззна... } & \multirow[b]{2}{*}{ Разреш... } & \multirow[b]{2}{*}{ Zerofill } & \multirow[b]{2}{*}{ По умолчанию } \\
\hline$\#$ & & & & & & & \\
\hline $\mathbf{1}$ & consumers_id & INI & 10 & $\square$ & $\square$ & $\square$ & AUTO_INCREM \\
\hline 2 & name & VARCHAR & 255 & $\square$ & $\nabla$ & $\square$ & NULL \\
\hline 3 & volume & FLOAT & & $\square$ & $\nabla$ & $\square$ & NULL \\
\hline 4 & lat & FLOAT & 10,6 & $\square$ & $\nabla$ & $\square$ & NULL \\
\hline 5 & Ing & FLOAT & 10,6 & $\square$ & $\nabla$ & $\square$ & NULL \\
\hline
\end{tabular}

Fig. 13. Structure of the consumers table 


\begin{tabular}{|c|c|c|c|c|}
\hline - consumers_id & $\nabla$ name & volume & lat & $\nabla$ lng \\
\hline 3 & Гоголево & 5 & 49.814365 & 34.169399 \\
\hline 13 & Шафранівка & 5 & 49.792542 & 34.121567 \\
\hline 14 & Camapi & 5 & 49.906456 & 34.111916 \\
\hline 10 & Чернишівка & 5 & 49.835079 & 34.083069 \\
\hline 11 & Тищенки & 5 & 49.781654 & 34.070210 \\
\hline 7 & Науменки & 5 & 49.799896 & 34.060215 \\
\hline 9 & Мала Бузова & 5 & 49.809433 & 34.038834 \\
\hline $\mathbf{8}$ & Велика Бузова & 5 & 49.782879 & 34.017681 \\
\hline 2 & Хвощове & 5 & 49.827271 & 34.013424 \\
\hline 12 & Шишаки & 5 & 49.874840 & 34.006046 \\
\hline 16 & Бухуни & 5 & 49.797157 & 33.966698 \\
\hline $\mathbf{1}$ & Яреськи & 5 & 49.836975 & 33.910965 \\
\hline
\end{tabular}

Fig. 14. Consumer table data

\begin{tabular}{|c|c|c|c|c|c|c|c|}
\hline$\#$ & Имя & Тип данных & Длина/Знач... & Беззна... & Разреш... & Zerofill & По умолчанию \\
\hline 1 & suppliers_id & INT & 10 & $\square$ & $\square$ & $\square$ & AUTO_INCREMI \\
\hline 2 & name & VARCHAR & 255 & $\square$ & $\square$ & $\square$ & NULL \\
\hline & volume & FLOAT & & $\square$ & $\nabla$ & $\square$ & NULL \\
\hline
\end{tabular}

Fig. 15. Suppliers table data

The "suppliers_to_consumers" table is a matrix of distances between a vehicle depot and raw material items (Fig. 16).
The "consumers to_consumers" table stores information about the communication between the items (Fig. 17, Fig. 18).

\begin{tabular}{|c|c|c|c|c|c|c|c|}
\hline & \# Имя & Тип даннык & Длина/Знач... & Беззна... & Разреш... & Zerofill & По умолчани \\
\hline & 1 id & INT & 10 & $\square$ & $\square$ & $\square$ & AUTO_INCRE \\
\hline 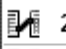 & 2 suppliers_id & INT & 10 & $\square$ & $\nabla$ & $\square$ & 0 \\
\hline 的 3 & 3 consumers_id & INT & 10 & $\square$ & $\nabla$ & $\square$ & 0 \\
\hline & 4 volume & FLOAT & & $\square$ & $\square$ & $\square$ & 0 \\
\hline
\end{tabular}

Fig. 16. Data from the "suppliers_to_consumers" table

\begin{tabular}{|c|c|c|c|c|c|c|c|}
\hline$\#$ & Имя & Тип данньк & Длина/Знач... & Беззна... & Разреш... & Zerofill & По умоль \\
\hline 1 & id & INI & 10 & $\square$ & $\square$ & $\square$ & AUTO_IN \\
\hline D冒盾 2 & point_id_a & INT & 10 & $\square$ & $\square$ & $\square$ & 0 \\
\hline D暞盾 3 & point_id_b & INT & 10 & $\square$ & $\square$ & $\square$ & 0 \\
\hline
\end{tabular}

Fig. 17. The structure of the table "consumers_to_consumers"

\begin{tabular}{||r|r|r|}
\hline 2 id & point_id_a & point_id_b \\
\hline $\mathbf{2 8 0}$ & 1 & 2 \\
\hline $\mathbf{2 8 4}$ & 3 & 2 \\
\hline $\mathbf{2 7 9}$ & 1 & 3 \\
\hline $\mathbf{2 8 1}$ & 1 & 12 \\
\hline $\mathbf{2 8 9}$ & 2 & 12 \\
\hline $\mathbf{2 8 5}$ & 3 & 12 \\
\hline $\mathbf{2 8 2}$ & 1 & 14 \\
\hline $\mathbf{2 9 0}$ & 2 & 14 \\
\hline $\mathbf{2 8 6}$ & 3 & 14 \\
\hline 291 & 12 & 14 \\
\hline
\end{tabular}

Fig. 18. Data from the table "consumers_to_consumers"

Algorithms, technologies and tools used. The following methods and algorithms are involved in the program: minimum element method, potential method, ant colony algorithm. JavaScript and PHP programming languages were used in the software implementation.
Ajax technology is enabled. Used JQuery library, Open Street Map to work with maps. Open Street Map, abbreviated OSM, is a non-profit, web-based mapping project to create a comprehensive free and free map of the world by a community of online users.

\section{Conclusions}

Commodity exchange and related transport flows play an important role in the economies of developed countries. The organization of transport flows requires the involvement of not only carriers but also service firms. The organization of flows of export, import and transit cargo was seen as a minor operation. In the USA, more than $90 \%$ of the volume of such cargo is organized by the freight forwarders, in Europe $70 \%$ of the intermodal transportations are for freight forwarding companies in Europe. In the national freight forwarding sector, there are a total of about 1000 enterprises providing freight forwarding and brokering services, 
most of which are unprofessional and do not have a well-developed integrated technology.

Studies show that $85-95 \%$ of the total duration of the logistics chain of the production cycle of the commodity movement is the expectation of processing, transportation and other operations, including storage. The goal of logistics is to build a door-to-door delivery process with minimal losses at the joints, with minimal cumulative costs and time to promote the integrated logistics flow.

The result of the research was the development of a system of optimization of transportation, which meets the modern requirements for software. The software is adapting to the Android platform.

\title{
REFERENCES
}

1. Kim, D.P. Automatic control theory. In 2 vols. Linear systems / D.P. Kim. - M .: FIZMATLIT, 2003. - 288 p.

2. Malhotra, R. Genetic Algorithms: Concepts, Design for Process Controller Optimization / R. Malhotra, N. Singh, Y. Singh // Computer and Information Science. - 2011. - Vol.4. - №2. - p. 39-54.

3. Hall, M. A Cumulative Multi-Niching Genetic Algorithm for Multimodal Function Optimization / M. Hall // International Journal of Advanced Research in Artificial Intelligence. - 2012. - Vol. 1. - № 9. - p. 6-13.

4. Jaen-Cuellar, A.Y. PID Controller Tuning Optimization with Genetic Algorithms in Servo Systems / A.Y. Jaen-Cuellar, R.de J. Romero-Troncoso, L. Morales-Velazquez, R. A. Osornio-Rios // International Journal of Advanced Robotic Systems. 2013. Vol. 10.

5. Jones, D.F. Multiobjective meta-heuristics: an overview of the current state-of-the-art / D.F. Jones, S.K. Mirrazavi, M. Tamiz // Europer Res, 2002. - 137 (1): 1-9.

6. Slavov, T. Application of Genetic Algorithm to Tuning a PID Controller for Glucose Oncentration Control / T. Slavov, O. Roeva // Electronic journal: Wsea Transaction on Systems. - 2012. - Vol. 11. - № 7. - p. 223-233. - URL: http://www.wseas.org/multimedia/journals/systems/2012/55-286.pdf

7. Konak, A. Multi-objective optimization using genetic algorithms: A tutorial / A. Konak, D.W. Soit, A.E. Smith // Reliability Engineering and System Safety 91 (2006). - P. 992-1007.

8. Horohorin, M.A. Genetic algorithm for constructing a fuzzy Pareto set / MA Horohorin, A.A. .Dolgov, Yu.V. Udodov, Yu.A. Gubskov // Devices and systems. Management, control, diagnostics. - M .: Nauchtechlitizdat, 2012. - №7. - P. $27-31$.

9. Podlazova, A. B., Genetic algorithms on examples of solution of cutting problems / A. B. Podlazova // Management problems, 2008. - № 2. - P. 57-63.

10. Denisova, L.A. Automation of synthesis of fuzzy control system using multicriteria optimization and genetic algorithms. Denisova // Automation in Industry, 2014. - №3. - P. 54-62.

11. Dunaev, M.P. Parametric optimization of a pumping station control system using a genetic algorithm. Dunaev, N.N. Kutsiy, N.D. Lukyanov // Science and Education: an electronic scientific and technical publication (electronic journal). - 2014. \# 8 URL: http://technomag.bmstu.ru/doc/721172.html (accessed: 08/25/2014).

12. Skakalina, E. Evolutionary algorithms in solving logistical . // "Modelare matematica, optimizare si technologii informationale", Materiale Conferintei Internationale, 19-24 martie 2018, vol.1, Chisinau.2018, P.310-315.

13. 13. Skakalina, E. (2018), «Development of Methodological Foundations of Logistical Intellectual Control of Complex Systems Based on Hybrid Heuristic Algorithms» / International Journal of Engineering \& Technology.- 2018.- Vol. 7, No (4.8). - P.534-538. DOI: 10.14419/ijet.v7i4.8.27301

14. Holland, J. H. Adaptation in Natural and Artificial Systems: An Introductory Analysis with Applications to Biology, Control, and Artificial Intelligence./ John H. Holland. - Cambridge: MIT Press, 1992. - 228p.

15. De Jong, K.A. Evolutionary computation a unified approach / K.A. De Jong. - Cambridge: A Bradford book, 2006. - 256 p.

\author{
Надійшла (received) 15.10.2019 \\ Прийнята до друку (accepted for publication) 11.12.2019
}

\section{Застосування мурашиних алгоритмів в рішенні задачі маршрутизації}

\section{О. В. Скакаліна}

Анотація. Дослідження показують, що 85-95\% загальної тривалості логістичного ланцюга виробничого циклу товарного руху становить очікування на обробку, транспортування та інші операції, включаючи зберігання. Мета логістики - побудувати процес доставки «від дверей до дверей» 3 мінімальними втратами на місцях з'єднання, 3 мінімальними накопичувальними витратами та часом для сприяння інтегрованому логістичному потоку. У статті розглядаються актуальні питання використання еволюційних алгоритмів для вирішення задачі маршрутизації. Мурашині алгоритми, як i більшість видів еволюційних алгоритмів, засновані на використанні популяції потенційних рішень і розроблені для вирішення завдань комбінаторної оптимізації, перш за все, пошуку різних шляхів на графах. Кооперація між особинами (штучними мурашками) тут реалізується на основі моделювання стігметріi. При цьому кожен агент, званий штучним мурахою, шукає рішення поставленого завдання. Штучні мурашки послідовно будують рішення завдання, пересуваючись по графу, відкладають феромон і при виборі подальшого ділянки шляху враховують концентрацію цього ферменту. Чим більше концентрація феромону в подальшому ділянці, тим більша ймовірність його вибору. Оскільки в основі мурашиного алгоритма лежить пересування мурах за деякими шляхах, то мурашині алгоритми ефективні, перш за все, при вирішенні завдань, які допускаю інтерпретацію у вигляді графа. Проведені комп'ютерні експерименти показали, що ефективність мурашиного алгоритма зростає при збільшенні розмірності задачі і для задач на графах високої розмірності вони працюють швидше, ніж інші еволюційні алгоритми. Відзначено також хороші результати при вирішенні нестаціонарних задач на графах зі змінною середовищем. В святи з цим пропонується реалізація мета - евристичного методу, як модифікації мурашиних алгоритмів оптимізації. Представлена схема роботи системи. Також представлена специфікація програмного продукту. Результатом дослідження стала розробка системи оптимізації перевезень, яка відповідає сучасним вимогам до програмного забезпечення. Програмне забезпечення адаптується до платформи Android.

Ключов і слов а : еволюційні алгоритми, задача маршрутизації, мурашині алгоритми оптимізації. 